\title{
Ecohydrological model for the quantification of ecosystem services provided by urban street trees
}

\author{
Roberto Revelli ${ }^{1,3}$ (D) . Amilcare Porporato ${ }^{2}$ \\ Published online: 17 February 2018 \\ (C) The Author(s) 2018, corrected publication July/2018
}

\begin{abstract}
Urban green spaces have been recognized as an important source of ecosystem services, whose quantification requires the determination of quantities related to energy, water, carbon and soil nutrient content. In this paper we propose a stochastic ecohydrological model that couples two existing models for water and nutrients in urban soil at the single street-tree scale. The model input are rainfall and irrigation, for water, and deposition and fertilization, for nitrogen, while the output are evapotranspiration, runoff and deep percolation, for water, and plant uptake and leaching, for nitrogen. The various terms are related to the amount of paved and impervious surfaces that surround the tree trunk and regulate the water and nutrient fluxes in and out the soil. Particular attention is paid to the effects of seasonal variations on plant water and nutrients through a temporal variation of the hydrologic variables (i.e., temperature and rainfall intensity and frequencies). The average model outputs are preliminarily compared with the scant existing literature data, supporting the model application to cities with different climatic conditions. The model results are used to estimate the potential for ecosystem services like tree cooling effects, soil carbon sequestration or storm-water management. Because of the minimal structure of the proposed model, it requires a very low amount of data, while accounting for the stochastic input of rainfall. In the context of climate change and increasing urbanization, the model may offer useful indications to urban planners to enhance ecosystem services while minimizing irrigation, fertilization and their related costs.
\end{abstract}

Keywords Ecosystem services $\cdot$ Ecohydrology $\cdot$ Urban green spaces $\cdot$ Street trees $\cdot$ Soil moisture $\cdot$ Nutrients . Soil carbon content $\cdot$ Pervious-impervious surfaces $\cdot$ Seasonality

\section{Introduction}

As the world's cities are becoming increasingly overcrowded and polluted, the expansion of land covered by impervious surfaces combined with climate change lead to new challenges for the relationship between people and urban ecosystems (Grimm et al. 2008; Pataki et al. 2011b; Sivapalan et al. 2012). Among the several components of

Roberto Revelli

roberto.revelli@duke.edu

Amilcare Porporato

aporpora@princeton.edu

1 DIATI, Department of Environment, Land and Infrastructure Engineering, Politecnico di Torino, Torino, Italy

2 Civil and Environmental Engineering and Princeton Environmental Institute, Princeton University, Princeton, NJ 084540, USA

3 Present address: Pratt School of Engineering, DUKE University, Durham, NC, USA the urban ecotone, green spaces play a significant role providing different ecosystem services (Tyrväinen et al. 2005). The development of models that embody the impact of human actions on water, energy, carbon and nutrient cycles that characterize the city context (Kaye et al. 2006) is crucial to the determination and quantification of ecosystem services (Bolund and Hunhammar 1999; Pataki et al. 2011a; Gómez-Baggethun and Barton 2013; Boerema et al. 2017) in current and future scenarios. A multidisciplinary approach is thus required to address the problem of making modern cities more livable and resilient (Meerow et al. 2016).

While a considerable effort is being devoted to define ecosystem services provided by urban green space (e.g., Byrne and Jinjun 2009), the actual methods for the quantification of their indicators and metrics are far from a mature stage; this is not only due to the undeniable complexity of the problem but also to the lack of a precise definition of many of these concepts.

The proposed tool here is an adaptation of ecohydrological models to provide a simple procedure for quantification 
of metadata necessary for evaluation of ecosystem services, i.e., an estimation of quantities like cooling effects, irrigation needs, plant stress, soil carbon content and nitrogen fluxes as a function of paved/impervious land covers and seasonal variability of hydroclimatic parameters. While the denomination of "urban green spaces" includes several configurations (e.g., green roofs, permeable vegetated surfaces, green alleys and streets, urban forests, public parks, community gardens, and urban wetlands, and, in general, every space where greeneries are present), here we focus in particular on urban street trees.

Urban street trees provide important benefits in terms of ecosystem services (Rosenberg et al. 2011; Young 2013; Salmond et al. 2016; Dobbs et al. 2017), including environmental, economic and social benefits (Mullaney et al. 2015b), attenuation of stormwater runoff, air quality improvement (Vos et al. 2013; Janhäll 2015; Russo et al. 2016), reduction of sound emissions from traffic and urban heat island effects and regulation of ambient temperature (Klemm et al. 2015), as well as greenhouse gas emission offset and reduction of nutrient leaching to groundwater (Nowak and Crane 2002; Byrne and Jinjun 2009; Brown et al. 2015; Byrne et al. 2015; Matthews et al. 2015; Nidzgorski and Hobbie 2016). Through the provision of ecological corridors, habitat and landscape connectivity, they increment biodiversity in urban ecosystems (Pitman et al. 2015; Shackleton 2016). Among the social benefits, urban trees enhance recreational opportunities and can play a significant role in reduction of stress (Thompson et al. 2012; Mace et al. 2005), crime activity, etc. (Kuo and Sullivan 2001; Maas et al. 2009).

Many studies have developed methods for the quantification of ecosystem services, e.g., ARIES, EcoServ-Gis, iTreeEco (Villa et al. 2014; Winn et al. 2016; i-Tree 2017; Yang et al. 2011; Bodnaruk et al. 2017), although often not specifically for the urban context (Derkzen et al. 2015). While some of these benefits of ecosystem services cannot be easily measured in terms of their of monetary value (McPherson et al. 2011), others may be more easily quantified. For example, street trees help to reduce energy costs and to increase property values. The mitigation of stormwater peak helps to minimize the required capacity, and thus cost, of drainage infrastructures and treatment systems. Shade and cooling effects contribute to abate energy costs in the warm season and may directly relate to lower emission of carbon dioxide, nitrogen dioxide, very fine particulate matter and volatile organic compounds.

Next to undoubted advantages, street trees can also be costly and disruptive to nearby buildings, infrastructures and paved surfaces like sidewalks and streets mostly due to roots extension, with consequent high costs for maintenance (Barker and Peper 1995; Blunt 2008; Mullaney et al. 2015a). Presence of insects, animals, pollen or leaf or branch fall my be perceived as a problem. Urban trees also need more maintenance and have a shorter life (up to 40 years) compared to natural environments (Mullaney et al. 2015b).

To minimize such problems, specie selection, root barriers and permeable/pervious paving materials (see, for example, Fig. 1) have increasingly become more used in urban areas. In particular measures to improve water, nutrient and oxygen availability for tree roots have become increasingly adopted, leading to reduction of vegetation stress and amelioration of stormwater management. Several measures aimed at water harvesting and reuse (Lucke and Beecham 2011) have also been implemented, aimed at increasing recharge to local water bodies and groundwater and improving water quality (Nidzgorski and Hobbie 2016). Particular attention should be also given to the soil composition in the root zone and the use of specific solutions, such as the "structural soil", can help to provide a good environment for root growth as well as a mitigation of breaking ad disrupting phenomena (see, for example, Grabosky and Bassuk 2016). Use of permeable surfaces is a common practice to make soils more conductive (Mullaney et al. 2015a) and to provide protection to pedestrian and vehicular traffic. Permeable surface can be made of different materials (e.g plastic or metallic grids, concrete elements, porous asphalt, etc...) or can be composed of modular elements (Scholz and Grabowlecki 2007; Mullaney and Lucke 2014). The number typologies is rapidly increasing and several commercial products have been created in last decades. Unfortunately the choice is often dictated more by esthetic reasons than ecohydrological ones. There are several studies that estimate surface permeability of materials used in urban environment, but most of them are related to stormwater mitigation problem. The following are specifically devoted to tree condition: Volder et al. (2009), Morgenroth and Buchan (2009), Johnson et al. (2011), Morgenroth et al. (2013), Volder et al. (2014), Song et al. (2015), Mullaney et al. (2015c), Grabosky and Bassuk (2016), and Kramer et al. (2015). However, since it remains difficult to assess their long-term effects, modeling is a promising direction especially to explore benefits of proposed solutions under different hydroclimatic conditions.

Our model presents a simple mathematical structure based on stochastic differential equations that link the stochastic and unpredictable nature of rainfall inputs to ecohydrological processes (i.e., evapotranspiration, irrigation, nutrient input and output) and then to a parsimonious formulation for the quantification of key ecosystem services. Differently from existing models that adopt a more cumbersome structure which requires extensive numerical simulations and inputs from measurements or weather simulators, our model relies on simple yet realistic representations of hydroclimatic forcing, whose impact on ecohydrological 
Fig. 1 Examples of bare soil extension and permeable/impervious configurations surrounding street tree installations. The last picture in row two refers to Chapel Hill (NC), others pictures refers to New York

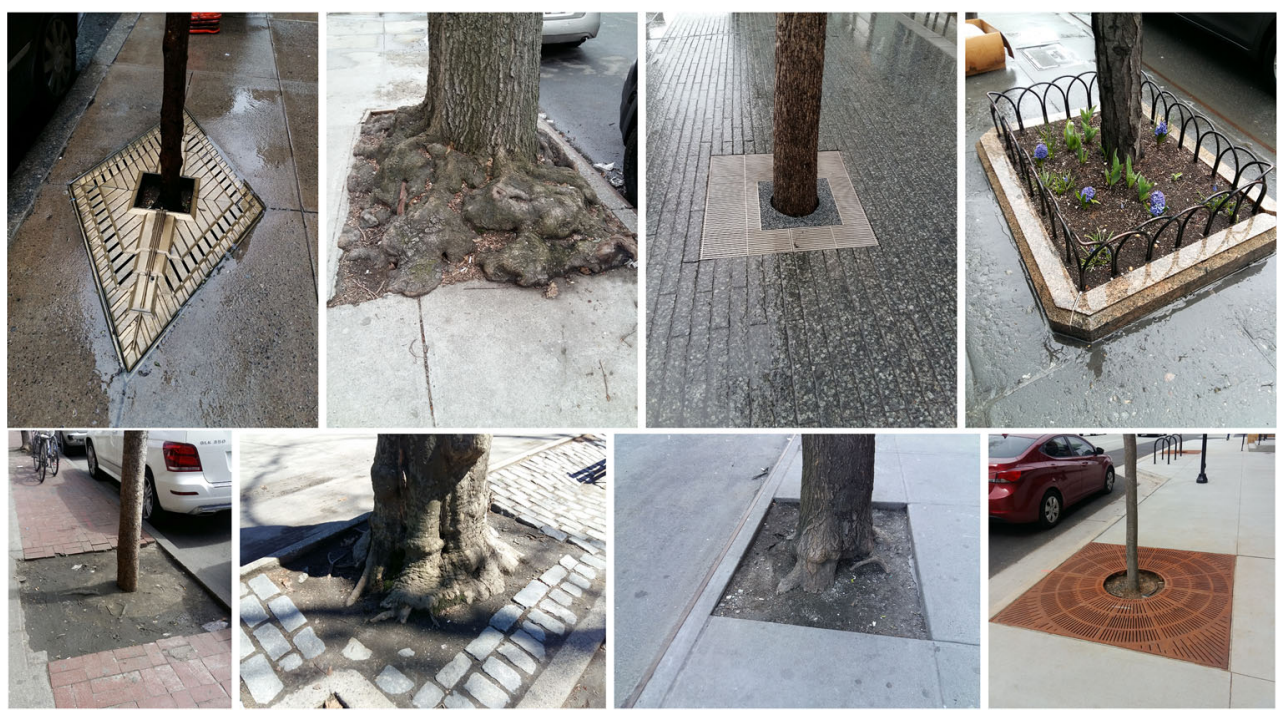

fluxes and ecosystem services can be quite easily explored for different climate conditions or architectural design for green areas and street trees management strategies. Moreover, the stochastic approach naturally incorporates in a mathematically rigorous manner the uncertainty and intermittency inherent in the rainfall patterns and the role of seasonality in both current and future climate scenarios. The minimalist approach allows us to obtain estimates only using reduced amount of data (i.e., mean rainfall depth and frequency and potential evapotranspiration, along with basic biogeochemical parameters), a fact that can be of extreme importance in urban contexts where the data availability is limited.

In summary, the scope of the work is to present a minimal approach that (1) gives a quantitative description of the problem, (2) is readily amenable to estimate ecosystem services, (3) requires a minimum amount of data, (4) can be applicable to different cities and, (5) can easily take in account parameter changes due to shifts in climatic or socioeconomic conditions (e.g., a change in rainfall frequency or increase in permeable surfaces). The estimated values can also help to quantify the effect of maintenance procedures, species selection or infrastructure improvements.

The paper is organized as follows: the first part focuses on the problem context and provides a conceptual scheme with emphasis on design characteristics and the extension of the ecohydrological model within the peculiarities of street tree conditions. Special attention is given to seasonal effects of hydroclimatic variability and possible changes in climate scenarios. The second part presents the model outcomes and ecosystem services evaluation for several selected cases along with a comparison with literature data. Perspectives and conclusions are discussed in the last section.

\section{Materials and methods}

\section{General model framework}

To begin exploring the feedbacks between soil water and mineral nitrogen $(\mathrm{N})$ including annual seasonality in both precipitation and available energy in the context of street trees, here we combine the model by Vico et al. (2014), which accounts for water balance components for street trees, with the nutrient dynamics model proposed in Porporato et al. (2003). A simple relationship between soil water and nutrient content is also used to obtain a preliminary quantification of soil carbon storage. The latter is useful in assessing soil carbon sequestration potential in relation to the evaluation of ecosystem service provided by street trees (see section: Quantification of ecosystem services).

Figure 2 shows a general scheme of the combined model. We consider a tree planted in a soil volume limited by nearby buildings and infrastructures. Trees receive water through rainfall and, when present, an irrigation system. They also receive nutrients by nitrogen deposition and, if provided, fertilization. The system loses water by evaporation, plant transpiration, runoff and deep percolation, while nutrients exit the soil through plant uptake and leaching. Within the soil, $\mathrm{N}$ undergoes several biogeochemical transformations due to mineralization and decomposition, while water and nutrient fluxes are regulated by physiological plant characteristics, climatic factors and boundary conditions (e.g., the presence of permeable/impermeable surfaces).

Table 1 shows a list of ecosystem services provided by street trees and specifically related to ecohydrological 


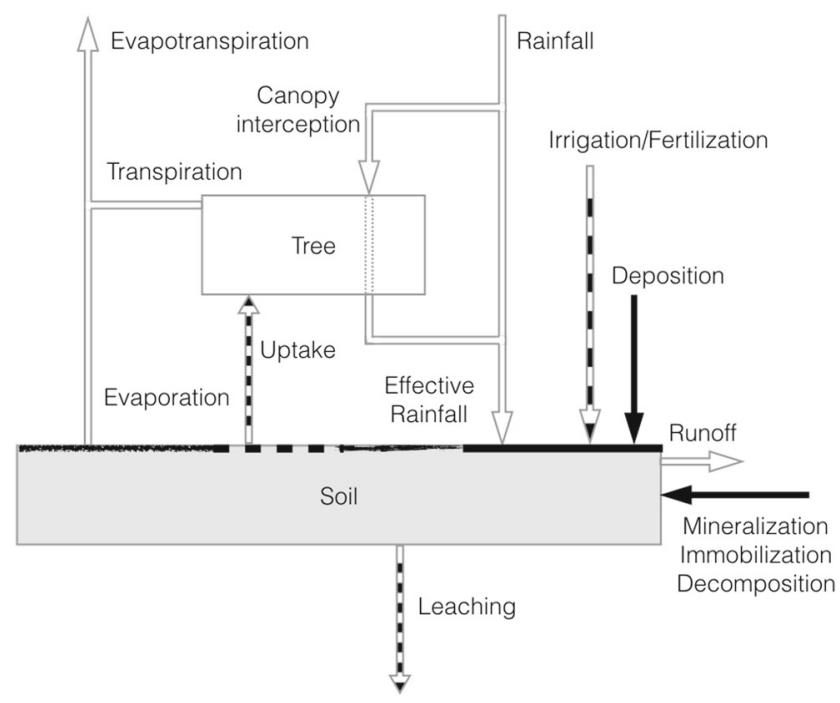

Fig. 2 Conceptual scheme of water and nutrient fluxes for a street tree. White and black arrows represent water and nutrient fluxes, respectively. Dotted line shows conceptual path of rainfall that is intercepted by canopy and then released to soil. The gray box is the root soil volume with corresponding soil moisture and mineral nitrogen content. The patched horizontal line on the top of the soil volume "idealizes" boundary with mixed permeabilities

processes that we take in account in the proposed model. The table also shows the direct or indirect influence of the governing variables (i.e., the soil moisture and nutrient contents) on the proposed ecosystem services and the strength of the management actions (i.e., more permeable area, irrigation and fertilization).

\section{Problem geometry and infiltration characteristics}

Surfaces near street trees can exhibit very different geometries and permeabilities. The presence of vehicular and pedestrian traffic, sidewalks, parking zones or infrastructures (and their maintenance as well as climatic, economic, historic and social conditions) in general dictate design and extension of these areas. We assume that soil is composed of three parts: a bare soil area, a more or less permeable area and an impermeable area. Hereinafter the subscripts $B$, $P$ and $I$ will refer to the three areas, respectively, while, the subscripts $R$ and $C$ will refer to roots and canopy extensions, respectively. For the sake of simplicity, we use a circular geometry so that the surfaces are characterized by their extensions, $A_{x}$ (with $x=B, P, I$ ), reference radii, $r_{x}$, and surface permeability coefficients $\eta_{x} \in[0,1]$. The latter denote the capacity of the area itself to let water and nutrients infiltrate into the root zone, being $\eta_{x}=1$ a totally permeable surface and $\eta_{x}=0$ an impermeable one.

The bare soil is often the nearest area closed to the tree trunk and its permeability depends on soil properties, climatic conditions and gardener practices (e.g., soil compaction and crust, mulching, hydrophobicity, etc...). There are many situations where this area can be very almost totally absent (see, for example, Fig. 1).

Regarding the permeable area, its characteristics depend on the adopted solution and used materials (e.g., plastic or metallic grids, concrete elements, porous asphalt, modular elements, etc...). The area characteristics are expressed by its extension and a specific coefficient $\eta_{P}$ that represents its surface permeability, i.e., the amount of water that infiltrate from the surface to the soil.

Finally, impermeable surfaces are present when trees are located near asphalted streets, sidewalks and parking lots. Water that falls on impermeable surfaces is mostly conveyed away by flow and stormwater control devices, although a certain part is able to reach root zone. For these we assume a variable fraction, i.e., $\eta_{I} \geq 0$, which depends on the design. The runoff could be eventually reused as input for the irrigation system but this harvesting possibility is not considered in the present paper.

The total amount of water that reaches the roots zone is assumed to be a function of canopy extension $\left(A_{C}\right)$, roots extension $\left(A_{R}\right)$ and geometry of bare soil and permeable/impermeable areas near tree. Root extension is dictated by presence of infrastructures, buildings and physical and/or chemical barriers specifically devoted to prevent damages caused by roots (Čermák et al. 2000; Morgenroth 2008). In the urban context the soil volume for roots is generally very low so that they tend to occupy all the available space; we consequently assume (Vico et al. 2014) that $r_{R}=r_{B}+r_{P}$ while $z_{R} A_{R}$ is the total soil volume considered in the model with $z_{R}$ a reference root depth. Typical of urban environments is also the fact that the soil system is disconnected from groundwater.

\section{Soil moisture dynamics}

The temporal dynamics of soil moisture (RodríguezIturbe and Porporato 2007) is given by the water balance between inputs (rainfall and irrigation) and outputs (evapotranspiration and deep percolation-runoff)

$n z_{R} A_{R} \frac{d s(t)}{d t}=R_{n}(t)-E T[s(t), t]-L_{e}[s(t), t]+I[s(t), t]$,

where $n$ is soil porosity while $s$ is soil moisture, state variable averaged over the roots soil volume $z_{R} A_{R}$. $R_{n}(t)$ is rainfall that effectively reaches the root zone, while $E T[s(t), t]$ and $L_{e}[s(t), t]$ represent losses from system due to plant and soil evapotranspiration and deep percolation/runoff, respectively. The last term, $I[s(t), t]$, is irrigation supply.

In the absence of irrigation, rainfall represents the only water input. Its unpredictability is accounted for 
Table 1 Ecosystem services and benefits related to processes included in the model. The variables influence can be direct (D) or indirect (I). The arrows indicate the direction of the action (increasing or decreasing) with respect the ecosystem service. The dimensions of the arrows indicate the relative importance of the action

\begin{tabular}{|c|c|c|c|c|c|c|c|}
\hline \multirow[t]{2}{*}{ Ecosystem service } & \multirow{2}{*}{$\begin{array}{l}\text { Main processes } \\
\text { involved }\end{array}$} & \multirow[t]{2}{*}{ Benefits } & \multicolumn{2}{|l|}{ Variables } & \multicolumn{3}{|c|}{ Management actions } \\
\hline & & & $\begin{array}{l}\text { Soil } \\
\text { moisture }\end{array}$ & $\begin{array}{l}\text { Soil nutrient } \\
\text { content }\end{array}$ & $\begin{array}{l}\text { Increasing } \\
\text { permeable } \\
\text { area }\end{array}$ & Irrigation & Fertilization \\
\hline $\begin{array}{l}\text { Water flow regulation } \\
\text { and stormwater retention }\end{array}$ & $\begin{array}{l}\text { Infiltration } \\
\text { Runoff } \\
\text { Canopy } \\
\text { interception }\end{array}$ & $\begin{array}{l}\text { Increased recharge } \\
\text { to groundwater } \\
\text { Reduced pressure on } \\
\text { urban drainage system }\end{array}$ & $\mathrm{D}$ & I & $\Uparrow$ & $\Downarrow$ & $\uparrow$ \\
\hline $\begin{array}{l}\text { Urban temperature regulation and } \\
\text { heat waves moderation }\end{array}$ & $\begin{array}{l}\text { Evapotranspiration } \\
\text { Canopy interception }\end{array}$ & $\begin{array}{l}\text { Evaporative cooling } \\
\text { Energy saving } \\
\text { Shading } \\
\text { Humidification }\end{array}$ & $\mathrm{D}$ & I & $\Uparrow$ & $\Uparrow$ & $\uparrow$ \\
\hline Carbon sequestration & $\begin{array}{l}\text { Photosynthesis } \\
\text { Litter storage }\end{array}$ & $\begin{array}{l}\text { Water retention } \\
\text { and soil fertility }\end{array}$ & I & I & $\uparrow$ & $\uparrow$ & $\uparrow$ \\
\hline $\begin{array}{l}\text { Water quality } \\
\text { and nutrient retention }\end{array}$ & $\begin{array}{l}\text { Leaching } \\
\text { Decomposition } \\
\text { Plant uptake } \\
\text { Deposition }\end{array}$ & $\begin{array}{l}\text { Reduced cost } \\
\text { of water treatment }\end{array}$ & I & $\mathrm{D}$ & $\uparrow$ & $\uparrow$ & $\downarrow$ \\
\hline
\end{tabular}

by considering $R_{n}(t)$ as a marked Poisson process, with effective frequency $\lambda_{n}(t)$ and effective mean rainfall depth $\alpha_{n}(t)$. The term "effective" is related to the rainfall quantity that actually reaches the soil after the canopy interception (see Eq. (6) and Eq. (7) in Vico et al. 2014).

The loss term ET includes evaporation and transpiration losses. Urban street trees are normally medium/large size trees planted in small areas of bare and permeable soil: for this reason, the soil water evaporation is generally less than plant transpiration. We can therefore assume that evapotranspiration losses can be included in a single function that depends on soil moisture and plant species through a reference transpiration rate $T_{r}$ and an indication of plant water stress $s^{*}$ (Cregg 1995; Nouri et al. 2013; Venkatraman and Ashwath 2016). A piecewise linear function is used to this purpose (see Eq. (5) in Vico et al. 2014) with the inclusion of a time dependence to account for seasonal variations in temperature, climatic conditions, photosynthesis, stomatal performances and respiration processes.

The term $L_{e}$ takes in account the overall losses due to surface runoff and deep percolation. For simplicity (e.g., Vico et al. 2014), these may be assumed to take place when soil moisture reaches a level $s_{1}$, between field capacity and saturation depending on presence of barriers, containers or infrastructures around the root sone.

The selection of an irrigation strategy is normally related to budget conditions, local regulatory laws and infrastructure availability (Nouri et al. 2013; Rosenberg et al. 2011). Following Vico and Porporato (2011) we account for "deficit irrigation" with a demand-based scheme that triggers irrigation when soil moisture reaches the intervention point, $\tilde{s}$ up to a soil moisture target level, $\hat{s}$. A "micro-irrigation" scheme, one where a continuous application of water balances evapotranspiration losses, is achieved when the target level coincides with the intervention point.

\section{Nutrient dynamic in the root zone}

The characterization of the soil-plant nutrient cycle and the related exchanges of organic and inorganic matter, nutrients and pollutants, is fundamental for the determination of ecosystem services provided by urban green spaces. As in the previous subsection, we assume a single pool, the soil root zone, and consider the mass balance of mineral nitrogen $(N)$ within the system. To quantify several useful indicators 
related to $N$ dynamics we begin by considering the mass balance equation of soil $\mathrm{N}$,

$\frac{d N(t)}{d t}=N_{\text {in }}(t)-N_{\text {out }}(s(t), t)$,

where $N_{\text {in }}$ and $N_{\text {out }}$ represent $\mathrm{N}$ fluxes that enter and exit soil system, respectively (Porporato et al. 2003). In particular, we assume (Fig. 2) that $N_{\text {out }}$ takes in account nitrogen losses due to plant uptake and water leaching. $N_{i n}$ includes $\mathrm{N}$ deposition, fertilization, net mineralization/immobilization and decomposition. Note that leaf litter can also contribute the soil nutrient balance (Bratt et al. 2017). In this way, the complex exchange processes between N pool and Soil Organic Matter (SOM) are included in $N_{i n}$ term.

Given the previous assumptions, input fluxes can be collected in the sum of two terms

$N_{i n}(t)=k_{i n} A_{n}+k_{m} f_{d s}(s)$,

where $k_{i n}$ is N input flux per unit of area, $A_{n}=\sum_{i}^{B, P, I} \eta_{i} A_{i}$ is the soil surface interested by water input in roots zone and the second term is a net term that takes in account mineralization, immobilization and decomposition processes and depend on soil moisture through a function $f_{d s}=s / s_{f c}$ for soil moisture below the field capacity $s_{f c}$ and $f_{d s}=s_{f c} / s$ otherwise (Rodríguez-Iturbe and Porporato 2007, p. 320), while $k_{m}$ is a net decomposition rate.

We assume nitrogen uptake to be proportional to plant evapotranspiration rate and nitrogen leaching proportional to soil moisture leaching and both of them proportional to $\mathrm{N}$ soil concentration. Therefore, the output nitrogen flux becomes

$N_{\text {out }}(s(t), t)=\frac{N(t)\left(E T(s(t), t)+L_{e}(s(t), t)\right)}{n z_{R} A_{R} s(t)}$,

where the denominator is necessary for dimensional reasons (see Rodríguez-Iturbe and Porporato 2007, p. 327-328).

\section{Seasonal forcing}

Seasonality, when present, drives the soil moisture and nutrient dynamics, and in turn controls the ecosystem services provided by urban green spaces, due to its controls on wet/dry periods, daylight duration, and high/low temperatures. Following Feng et al. (2014) we consider seasonality effects on water and nutrient cycles in the temporal variation of forcing parameters, namely rainfall frequencies $\lambda(t)$ and depths $\alpha(t)$ and energy related to evapotranspiration $T(t)$.

We assume that effective rainfall frequency and mean rainfall depth are related to monthly wet days and to mean monthly rainfall depth with value assigned to midmonth and a linear variation for the determination of daily values. For the estimation of transpiration $T(t)$ we calculate potential evapotranspiration with the widely used PriestleyTaylor model (Peters et al. 2011) that we rescale with respect different reference mean transpiration values $T_{r}$ during the growing season depending on the examined tree specie.

\section{Quantification of ecosystem services}

Given the outputs of the model, including the soil water and $\mathrm{N}$ concentration as well as the water and $\mathrm{N}$ fluxes in and out the system, it is possible to quantify some ecosystem services provided by urban street trees.

Carbon sequestration clearly depends on the characteristics of trees but also on the amount of pervious surfaces (Nowak and Crane 2002; McPherson et al. 2013; Velasco et al. 2016). Following the simple approach of Rohr et al. (2013) we suppose that the soil carbon is proportional to soil nitrogen content and to biomass that, in turn, is related to soil water content, i.e.,

$C=k(C / N) N(t) B(s)$,

where $k$ is a proportionality constant between nitrogen content in Soil Organic Matter $\left(N_{S O M}\right)$ and mineral nitrogen, $(C / N)$ is the ratio between carbon and nitrogen content (see, for example, Raciti et al. 2008) and $B(s)$ represents the dependence of biomass on soil moisture. We assume (Rohr et al. 2013) that $B(s)$ goes linearly between a minimum value in correspondence of the wilting point $s_{w}$ and a maximum value for soil moisture equal to the field capacity $s_{f c}$. In this way, even for very low values of soil moisture, a biomass is present through the presence of litter and organic residues in soil.

The possibility of soil moisture of being under a stress threshold is crucial to both the tree esthetic quality and its cooling capacity (Bowler et al. 2010; Gago et al. 2013). In general, energy losses by tree evapotranspiration are estimated with canopy and boundary layer models, radiation and temperature models and through an accurate analysis of the geometrical conditions like position of the tree with respect nearest buildings, shading effects, and street canyon features (Yang et al. 2013; Calcerano and Martinelli 2016; Kong et al. 2016; Zoelch et al. 2016). Here we simply assume that cooling effect is related to evapotranspiration term through latent vaporization heat and the mean saving, $S$, is estimated as

$\left.S=\lambda_{e} \int c(t) H(t) E T[s(t), t)\right] d t$,

where $c$ is the $k W h^{-1}$ energy cost, $H$ is the number of daylight hours and $\lambda_{e}=2264.76 \mathrm{KJ} / \mathrm{kg}$ is the latent heat of vaporization and the integral is extended to the temporal interval of interest (typically the summer season). 
Table 2 Climatic data for the considered cities

\begin{tabular}{lllllrrrr}
\hline City & Lat. & Long. & Alt $[\mathrm{m}]$ & $\mathrm{R}[\mathrm{mm}]$ & $\mathrm{WD}[\mathrm{d}]$ & Tmin. $\left[{ }^{\circ} \mathrm{C}\right]$ & $\mathrm{Tmax} .\left[{ }^{\circ} \mathrm{C}\right]$ & $\mathrm{KG}$ \\
\hline${\text { Durham }(\mathrm{NC}-\mathrm{USA})^{\mathrm{a}}}$ & $35.9886^{\circ} \mathrm{N}$ & $78.9072^{\circ} \mathrm{W}$ & 123 & 1221 & 89 & -2.3 & 31.4 & $\mathrm{Cfa}$ \\
Minneapolis (MN - USA) $^{\mathrm{a}}$ & $44.8831^{\circ} \mathrm{S}$ & $93.2289^{\circ} \mathrm{W}$ & 264 & 783 & 117 & -9.1 & 23.2 & $\mathrm{Dfa}$ \\
Palermo (Italy) $^{\mathrm{b}}$ & $38.1156^{\circ} \mathrm{N}$ & $13.3613^{\circ} \mathrm{E}$ & 14 & 833 & 81 & 10.4 & 30.0 & $\mathrm{Csa}$ \\
Serra Talhada (Brasil) $^{\mathrm{c}}$ & $7.9836^{\circ} \mathrm{S}$ & $38.2928^{\circ} \mathrm{W}$ & 444 & 666 & 68 & 16.5 & 31.2 \\
\hline
\end{tabular}

Lat.—latitude, Long.—longitude, Alt.—mean altitude above see level, R—annual rainfall, WD—wet days per year, Tmin.—min monthly averaged min temperature, Tmax.—max monthly averaged max temperature, KG—Köppen-Geiger climatic classification

${ }^{a}$ National Oceanic and Atmospheric Administration www.ncdc.noaa.gov

${ }^{b}$ APAC Pernambuco Agency of Water and Climate www.apac.pe.gov.br

${ }^{\mathrm{c}}$ Sicily Regional Council www.osservatorioacque.it

Finally, one of the well recognized ecosystem services provided by urban vegetation is its capacity to reduce runoff and, in turn, the need of stormwater facilities. The partitioning of water between the different terms allows us to estimate the volume of stormwater facilities as proportional to water losses due to run off and deep percolation. In this case we simply define the ecosystem service as the percentage of rainfall that become in the deep percolation and runoff.

\section{Selected cases}

Four selected cases (Table 2) were chosen as test cases to encompass different climatic conditions and hydrologic constraints and focus on the quantification of water stress or nitrogen limiting conditions. Durham and Palermo (Fig. 3) belong to temperate (mesothermal) and Mediterranean climate respectively, Minneapolis to continental (microthermal) climate and Serra Talhada to tropical dry climate. Durham shows a quite constant rainfall behavior through the year with great amount of total annual rain. Minneapolis temperatures can be medium in summer and become very low in winter and go below freezing. The number of wet days is very high even if total annual amount of rainfall is not so high. Palermo presents a typical arid situation with rainfall concentrated during Winter and very low rainfall during Summer, high temperatures during Summer without freezing conditions during Winter. Serra Talhada shows high and constant, or almost constant without great variability, temperatures and rainfall practically concentrated in a couple of months (from February to March).

Climatic data were obtained from online datasets: net radiation data from NASA database CERES (Clouds and the Earth's Radiant Energy System-https://ceres.larc.nasa. gov/), rainfall and temperature data from National Oceanic
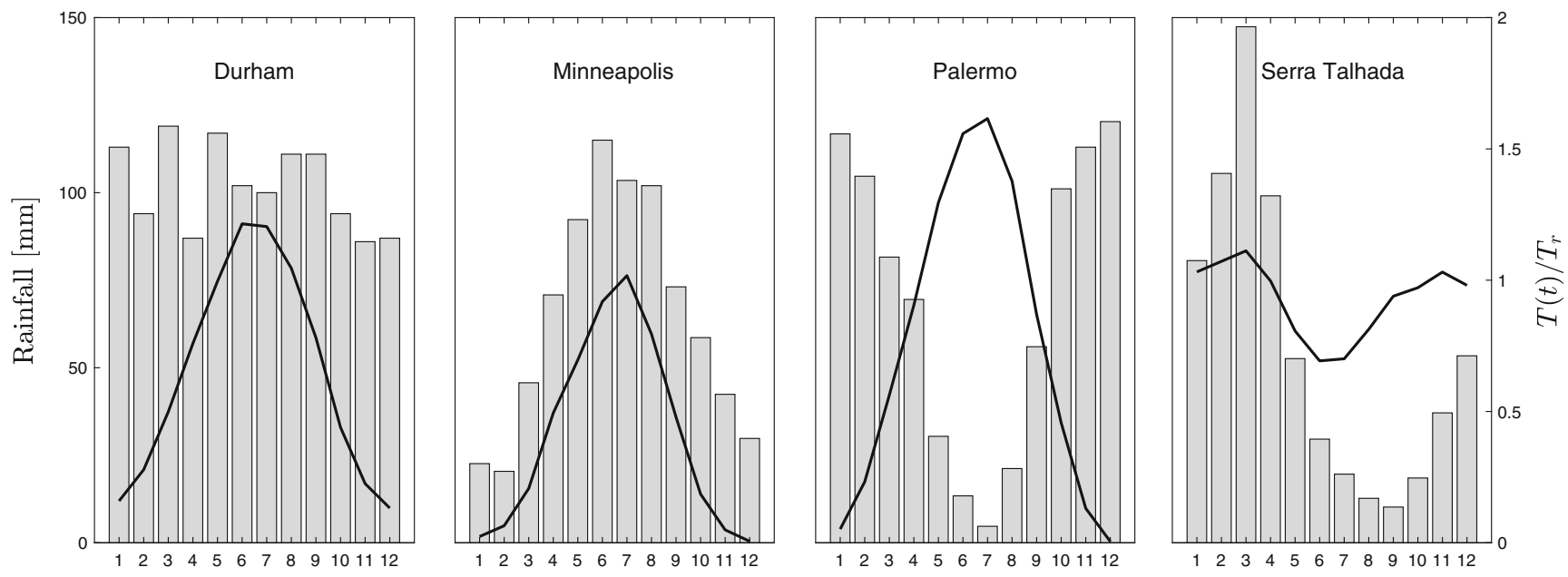

Months of the Year

Fig. 3 Climatic condition (monthly rainfall (bars) and evapotranspiration (black line)) for the four analyzed cities. Evapotranspiration is normalized with respect to $T_{r}=80 \mathrm{~kg}$ per day per tree. Net radiation data from NASA database CERES (Clouds and the Earth's Radiant Energy System-https://ceres.larc.nasa.gov/) 
and Atmospheric Administration (www.ncdc.noaa.gov)Durham and Minneapolis, APAC Pernambuco Agency of Water and Climate (www.apac.pe.gov.br)—Serra Thalada and Sicily Regional Council (www.osservatorioacque. it)-Palermo. Model parameters (Table 3) have been inferred from the literature (Peters et al. 2010; Vico et al. 2014; Parolari and Porporato 2016; Nidzgorski and Hobbie 2016), while typical geometries and canopy extensions have been deduced from municipal guidelines (see, for example, https://www.nycgovparks.org/pagefiles/ 53/Tree-Planting-Standards.pdf).

It is clear that in principle each parameter of the model depends on the examined position, tree species and local soil conditions. However for sake of simplicity and to concentrate our attention on different climatic conditions, seasonality, geometry, soil permeability and tree species we focus here on the role of the permeable $r_{P}$ and impermeable

Table 3 Model parameters used in the simulations

\begin{tabular}{|c|c|c|c|}
\hline \multicolumn{2}{|l|}{ Parameter } & \multirow{2}{*}{$\frac{\text { Units }}{\mathrm{m}}$} & \multirow{2}{*}{$\begin{array}{l}\text { Value(s) } \\
0.45\end{array}$} \\
\hline Mean root depth & $z_{R}$ & & \\
\hline Soil porosity & $n$ & - & 0.43 \\
\hline Canopy interception depth & $\Delta$ & $\mathrm{m}$ & 0.001 \\
\hline Reduction coefficient & $\kappa_{C}$ & - & 0.6 \\
\hline Intervention point & $\tilde{s}$ & - & $0.75 s^{*}$ \\
\hline Target point & $\hat{s}$ & - & $0.8 s_{1}$ \\
\hline Field capacity & $s_{f c}$ & - & 0.60 \\
\hline Soil moisture when leaching occurs & $s_{1}$ & - & 0.61 \\
\hline Soil moisture at wilting point & $s_{w}$ & - & 0.21 \\
\hline Canopy area radius & $r_{C}$ & $\mathrm{~m}$ & 3.5 \\
\hline $\mathrm{N}$ input flux per unit area & $k_{\text {in }}$ & $\mathrm{g} \mathrm{N} \mathrm{m}^{-2} \mathrm{~d}^{-1}$ & $5.5 \cdot 10^{-3}$ \\
\hline $\mathrm{N}$ net decomposition rate & $k_{m}$ & $\mathrm{~d}^{-1}$ & 0.1 \\
\hline Bare soil radius & $r_{B}$ & $\mathrm{~m}$ & 1 \\
\hline Bare soil permeability & $\eta_{B}$ & - & 1 \\
\hline Impermeable soil contribute & $\eta_{I}$ & - & 0.1 \\
\hline Soil C:N & $C / N$ & - & 70 \\
\hline $\mathrm{N}_{\mathrm{SOM}}: \mathrm{N}$ & $k$ & - & 100 \\
\hline Daylight hours & $H$ & $\mathrm{~h}$ & 16 \\
\hline Energy cost & $c$ & $\$ \mathrm{kWh}^{-1}$ & 0.12 \\
\hline Permeable soil radius & $r_{P}$ & $\mathrm{~m}$ & $0-5$ \\
\hline Impermeable soil radius & $r_{I}$ & $\mathrm{~m}$ & $0-5$ \\
\hline Root area radius & $r_{R}$ & $\mathrm{~m}$ & $1-6$ \\
\hline Permeable soil permeability & $\eta_{P}$ & - & $0-1$ \\
\hline Plant water stress & $s^{*}$ & - & $0.23-0.28$ \\
\hline Reference transpiration per tree & $T_{r}$ & $\mathrm{~kg} \mathrm{~d}^{-1}$ & $60-100$ \\
\hline
\end{tabular}

In the first part the table shows the parameters kept constant while the second part gives the range of the parameters varied between the simulations. Data inferred from Peters et al. (2010), Vico et al. (2014), Parolari and Porporato (2016), and Nidzgorski and Hobbie (2016)
$r_{I}$ soil radii, the root area radius $r_{R}$ and the permeable soil permeability $\eta_{P}$. The behavior of different tree species are explored with reference to two parameters: the plant water strees $s^{*}$ and the reference transpiration rate $T_{r}$. In particular for this latter a value $T_{r}=80 \mathrm{~kg} \mathrm{~d}^{-1}$ per tree can be considered as an indicative mean value for several species (see, for example, Peters et al. 2010). The results for this typical case are reported with black lines in the Figures that follow. To analyze the consequence of a management decision that introduces species with a more or less tolerance to drought conditions, we also consider a reference transpiration rate equal to $\pm 25 \%$ of $T_{r}$. The first case (i.e., $T_{r}=60 \mathrm{~kg} \mathrm{~d}^{-1}$ per tree) is indicated with red lines, while the second one (i.e., $T_{r}=100 \mathrm{~kg} \mathrm{~d}^{-1}$ per tree) is showed with green lines.

For every configuration, we carried out an ensemble of 5000 realizations with an explicit finite difference method and with a temporal step sufficiently low to ensure numerical stability. The beginning of the runs were discarded to avoid influence of the initial conditions.

\section{Results and discussion}

Model results were qualitatively validated using experimental data by Nidzgorski and Hobbie (2016) that measured N leaching from 2011 to 2013 in three city parks (Carty, College and Horton) in Saint Paul, Minnesota, US. Values were collected in soils under 33 healthy, mature trees (Abies concolor, Acer platanoides, Acer saccharinum, Celtis occidentalis, Fraxinus pennsylvanica, Ginkgo biloba, Gleditsia triacanthos, Pinus ponderosa, Pinus resinosa, Pinus strobus, Pinus sylvestris, Quercus macrocarpa, Tilia cordata) with Diameter at Breast Height (DBH) ranging from 20 to $90 \mathrm{~cm}$ and heights spanning from 8 to $22 \mathrm{~m}$. Nidzgorski and Hobbie (2016) estimate leaching values equal to 4.1-7.1 mg Nm${ }^{-2} \mathrm{~d}^{-1}$ and $1.4-5.7 \mathrm{mg} \mathrm{Nm}^{-2} \mathrm{~d}^{-1}$ for evergreen and deciduous, respectively. In similar situations Gundersen et al. (1998) propose $0-0.5 \mathrm{mg} \mathrm{Nm}^{-2} \mathrm{~d}^{-1}$, Strahm et al. (2005) evaluate leaching as $0.1-1.4 \mathrm{mg} \mathrm{Nm}^{-2} \mathrm{~d}^{-1}$, while Amador et al. (2007) report $1.9 \mathrm{mg} \mathrm{Nm}^{-2} \mathrm{~d}^{-1}$. Figure 4 shows the leaching fluxes for four different configurations compared with the aforementioned indications. As expected, larger permeable area increase water and $\mathrm{N}$ infiltration in the roots soil zone but also induce greater leaching especially during the Spring season. In particular, (1) the mean leaching is comparable with experimental indications, (2) the maximum occurs during most intense rainfall (April-May), (3) there is a rapid decrease during the growing season, (4) there are two minima located in late summer and during winter season and, (5) there is a delay of 3-5 days between water and $\mathrm{N}$ leaching fluxes. 


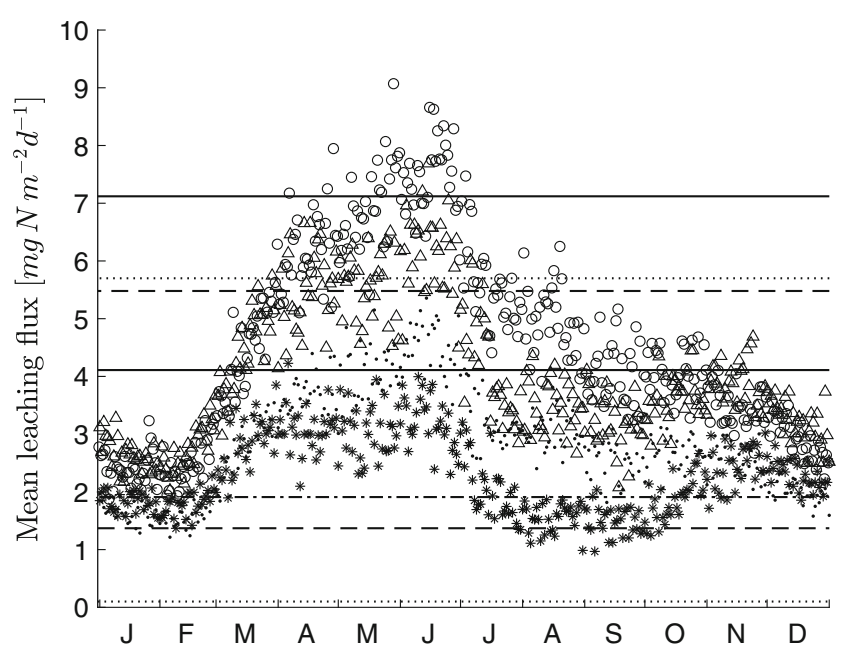

Fig. 4 Mean daily nitrogen leaching flux for Minneapolis used for model calibration: $(\triangle) r_{P}=3 \mathrm{~m}$ and $\eta_{P}=0.9$, (*) $r_{P}=3 \mathrm{~m}$ and $\eta_{P}=0.6$, (०) $r_{P}=4 \mathrm{~m}$ and $\eta_{P}=0.9$ and (.) for $r_{P}=$ $4 m$ and $\eta_{P}=0.6$. Lines indicate experimental values: continuos lines refer to deciduous trees while dashed lines refer to evergreen plants (Nidzgorski and Hobbie 2016). Dotted lines refer to the range proposed by Gundersen et al. (1998) while the dot-dashed line refers to Amador et al. (2007). See also Iseman et al. (1999) and Qin et al. (2013)

\section{Soil moisture content and irrigation needs}

Use of irrigation for green urban spaces is a controversial question especially in cities that experience water shortage and where restrictions on water use are rapidly increasing. The determination of water amount necessary to maintain ecosystem services provided by urban trees can thus be critical to inform local policies and decisions.

We begin by considering the "rainfed case". The mean soil moisture trends are presented in Fig. 5 for the four cities considered as test cases. To emphasize the role of permeable/impermeable surfaces, mean soil moisture is comparatively showed with all parameters kept constant except hydrologic and climatic conditions and length of permeable zone. As expected, there is a great influence of paved surface extension on soil moisture behavior. For Durham and Minneapolis, when permeable surface is larger than impervious one, mean soil moisture is near $s_{1}$ value (i.e., where leaching occurs) and it presents low values only during warmest months. Palermo shows similar behavior but values are always very low for several months and with large impervious surfaces can be easily near zero. As expected, Serra Talhada shows an extremely unfavorable environment for plant wellbeing because soil moisture values are very low for great part of year, with exception during warmest months. If we consider $s^{*}$ as plant incipient water stress (horizontal line in Fig. 5) we note that for Minneapolis and Durham a value of $r_{P}=2-2.5 m$ can be a good indication in order to ensure a sufficient soil moisture availability for plants while for Serra Talhada this condition can be reached only with larger extension of the paved surface (i.e., $r_{P}=4-4.5 m$ ) and with a very high permeability. In Palermo, the mean soil moisture is always under $s^{*}$ threshold value for a period that range from MarchOctober for $r_{P}=0 \mathrm{~m}$, to May-September for $r_{P}=2.5 \mathrm{~m}$, to August for $r_{P}=5 \mathrm{~m}$. In other words, in this case it is not possible to prevent plant water stress during summer without a suitable irrigations system.

It is also useful to calculate the amount of irrigation water necessary to keep a given soil moisture level. In Fig. 6 an estimation of annual water volume per tree for Palermo with a "traditional" scheme (left panel) and "microirrigation" system (right panel) are reported. As expected, traditional irrigation requires a greater amount of water with respect microirrigation system. Figures also demostrate the nonlinear behavior with respect to paved/impervious extension and permeability of permeable surface and how with low extension of permeable surface we require great amount of needed water. The lines tend to be horizontal with low $n_{p}$ and high $r_{p}$, reflecting the fact that surface permeability is more important for high values of permeable area extension. Figures also shows water irrigation estimation for two different tree species related to two different $s^{*}$ values and let to estimate the irrigation needed with respect the selected species that, for simplicity, we assume related to a proper value of $s^{*}$. As aspected the higher the $s^{*}$, the higher the water volume necessary to maintain the soil moisture level above a incipient stress threshold.

The efficiency of proposed paved solutions can be evaluated trough a series of partition coefficients. Figure 7 shows (Durham case and without irrigation) the percentage of rainfall (left panel) that effectively reaches roots soil volume and (right panel) how much of these effective rainfall is lost by run-off and deep percolation (the complement to this latter being evapotranspiration losses). It is evident that the extent of the impervious surface plays a fundamental role in determining water efficiency of the system: with a low amount of permeable surface the rainfall volume that reaches the soil roots zone can be less that $10 \%$.

Finally, the effects of different tree species on soil moisture content is also evident in Figs. 5, 6 and 7. Red and green lines refer to two reference evapotranspiration terms $\left(T_{r}=60 \mathrm{kgd}^{-1}\right.$ and $T_{r}=100 \mathrm{kgd}^{-1}$, respectively). As expected the higher the reference transpiration rate, the lower the soil moisture content and viceversa, the lower the reference transpiration rate, the lower the volume of water necessary for the irrigation. The difference can be over the $50 \%$ and this testifies how a careful choice of the tree specie can have a great influence on water budget management. On the other hand, the lower the reference transpiration rate the higher the percentage of total rain that is lost by leaching. 
Fig. 5 Mean soil moisture in rainfed conditions for a Durham, b Minneapolis, c Palermo, d Serra Talhada. The horizontal lines represent $s^{*}=0.28$ value. Figures refer to $\eta_{P}=0.6$. The black curves refer to a tree with $T_{r}=80 \mathrm{~kg}$ $\mathrm{d}^{-1}$ and to $r_{P}$ equispaced values between $r_{P}=0 \mathrm{~m}$ to $r_{P}=5 \mathrm{~m}$. Bold lines represent $r_{P}=0 \mathrm{~m}$ (continuous), $r_{P}=2.5 \mathrm{~m}$ (dot-dashed) and $r_{P}=5 \mathrm{~m}$ (dashed), respectively. The red and green dot-dashed bold lines refer to $r_{P}=2.5 \mathrm{~m}$ and a tree with $T_{r}=60 \mathrm{~kg} \mathrm{~d}^{-1}$ and $T_{r}=100 \mathrm{~kg} \mathrm{~d}^{-1}$, respectively (see text). Other values are reported in Table 3
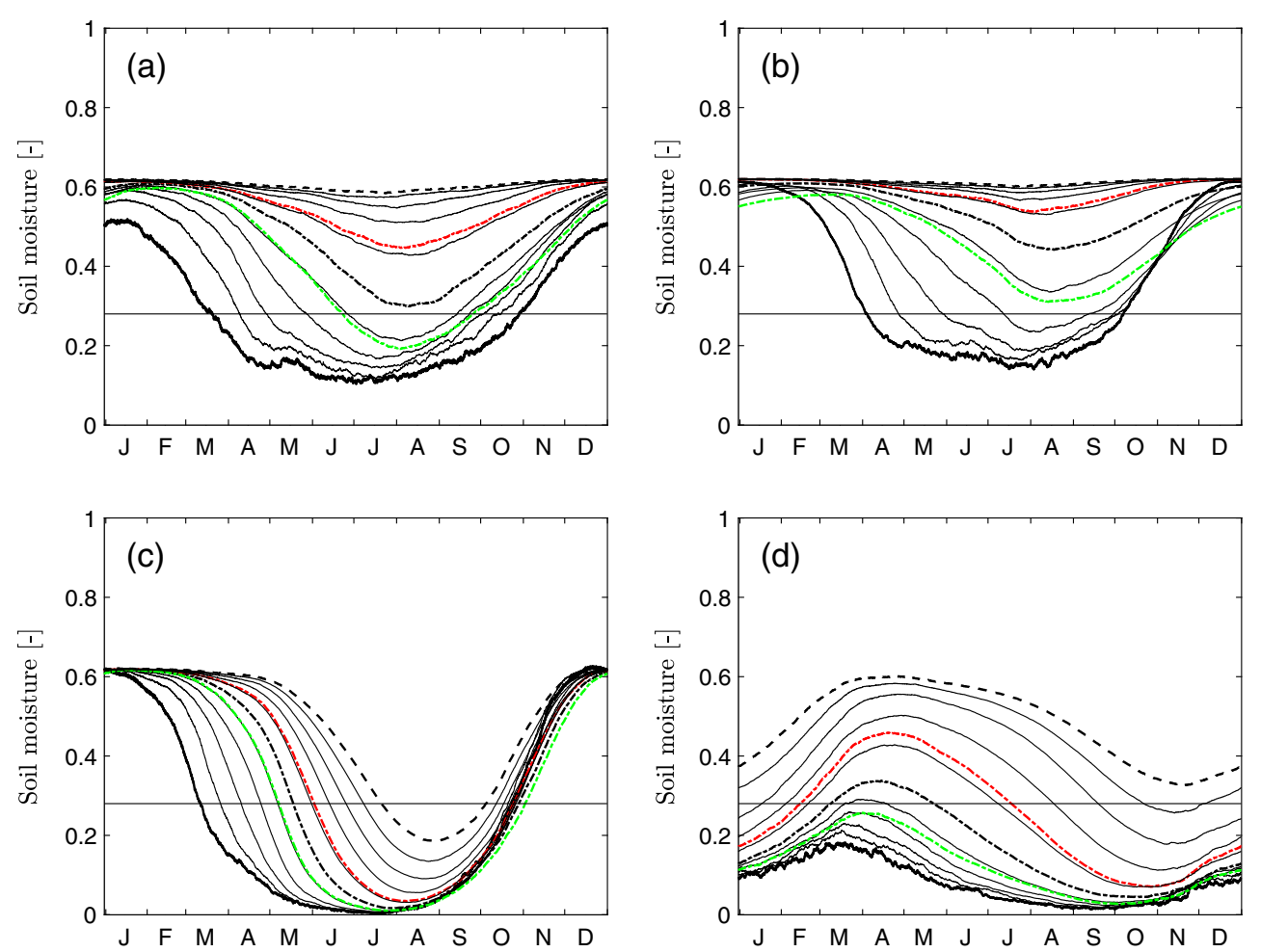

However this difference is offset by the benefits of reduced water use.

\section{Nutrient plant uptake}

Assessment of fertilization policies and related costs and benefits (see Table 1) greatly depends on the knowledge of soil nutrient concentration and plant uptake. When these latter values go below certain thresholds (that mostly depend on plant specie) it is necessary to provide nutrient through fertilization to maintain good level of ecosystem services.

Table 4 shows a summary of estimated mean nitrogen concentration for situation ranging from very impervious zones to very permeable zones: in general, mean nitrogen concentration grows with extension of permeable surface and with increasing surface permeability.

Figure 8 shows nitrogen plant uptake, calculated in term of nitrogen mass per day per unit area. Figures also show indicative nitrogen values from the literature (e.g., Ma et al. 2008; BassiriRad et al. 2008; Wang et al., 2008) that report an annual nitrogen uptake range of $20-120 \mathrm{Kg} \mathrm{ha}^{-1}$ in temperate forest ecosystem, $30-70 \mathrm{Kg} \mathrm{ha}^{-1}$ in xeric system, up to $270 \mathrm{Kg} \mathrm{ha}^{-1}$ in mesic systems, as well as $50 \mathrm{Kg} \mathrm{ha}^{-1}$ which is typical in crop production systems. The flux per unit area is clearly reduced when there is a great root area extension and the proposed model captures the order of magnitude of $\mathrm{N}$ flux uptake. The Figure also evidences the dependence of nitrogen uptake on seasonality. As aspected,
Fig. 6 Annual irrigation volume $\left(\right.$ in $\mathrm{m}^{3}$ ) per tree for Palermo with traditional irrigation (left panel) and microirrigation approach (right panel). Continuous and dashed lines refer to $s^{*}=0.28$ and $s^{*}=0.23$, respectively. Red, black and green lines represent a tree with a $T_{r}=60 \mathrm{kgd}^{-1}, T_{r}=80 \mathrm{kgd}^{-1}$, and $T_{r}=100 \mathrm{kgd}^{-1}$, respectively (see text). Other values are reported in Table 3
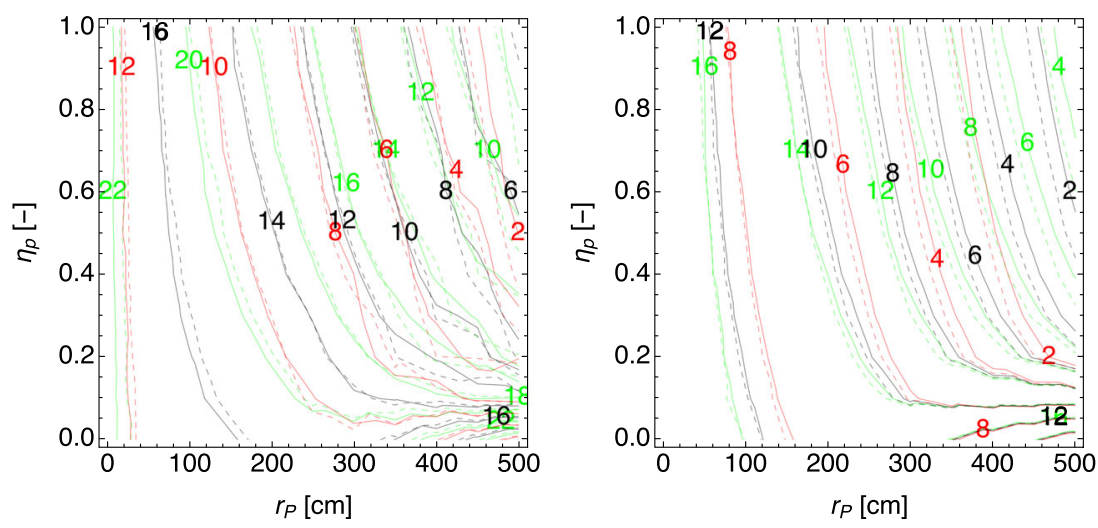
Fig. 7 Rainfall partitioning between rainfall, transpiration and leaching for the case of Durham. Left panel: percentage of effective rainfall with respect total rainfall that reaches roots soil zone. Right panel: percentage of total rain that is lost by leaching. Percentages are reported with respect the extension of permeable surface and its permeability. Black, red and green lines as in Fig. 6. Other values are reported in Table 3

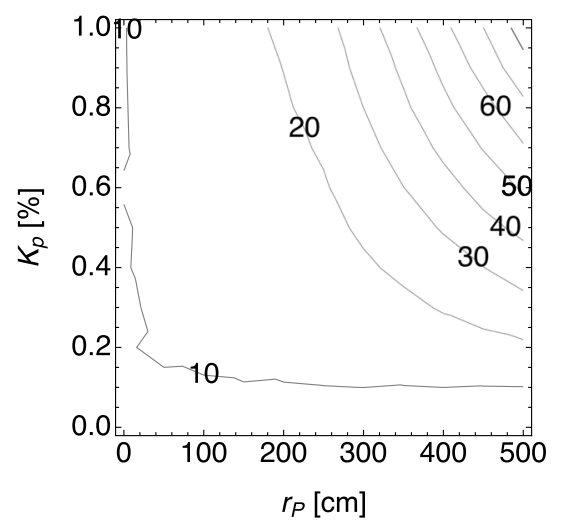

Table 4 Calculated mean nitrogen concentration $[\mathrm{mg} / \mathrm{L}]$

\begin{tabular}{|c|c|c|c|c|c|c|c|c|c|c|}
\hline \multirow[b]{2}{*}{ City } & \multirow[b]{2}{*}{$\eta_{P}$} & \multicolumn{3}{|c|}{$r_{P}=1 \mathrm{~m}$} & \multicolumn{3}{|c|}{$r_{P}=2 \mathrm{~m}$} & \multicolumn{3}{|c|}{$r_{P}=4 \mathrm{~m}$} \\
\hline & & $10 \%$ & $50 \%$ & $90 \%$ & $10 \%$ & $50 \%$ & $90 \%$ & $10 \%$ & $50 \%$ & $90 \%$ \\
\hline Durham & & 0.23 & 0.27 & 0.32 & 0.34 & 0.57 & 0.76 & 0.67 & 1.90 & 2.09 \\
\hline Minneapolis & & 0.36 & 0.44 & 0.51 & 0.49 & 0.90 & 1.21 & 0.96 & 2.88 & 3.16 \\
\hline Palermo & & 0.22 & 0.25 & 0.28 & 0.35 & 0.53 & 0.65 & 0.61 & 1.68 & 2.05 \\
\hline Serra Talhada & & 0.06 & 0.08 & 0.09 & 0.14 & 0.24 & 0.34 & 0.40 & 1.38 & 2.49 \\
\hline
\end{tabular}
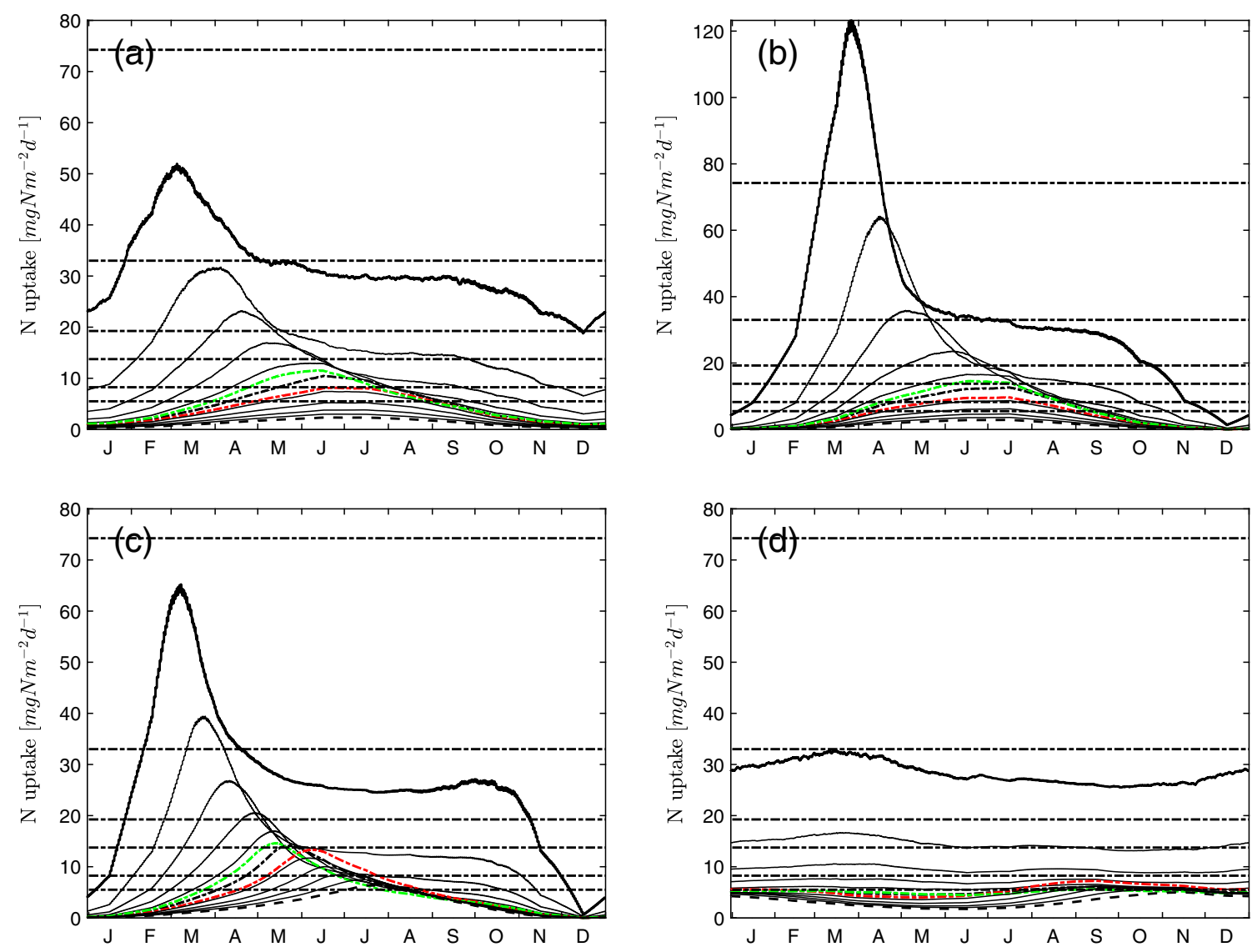

Fig. 8 Plant nitrogen uptake: a Durham, b Minneapolis, c Palermo, d Serra Talhada. Parameters, line styles and colors are the same as in Fig. 5. The horizontal lines show six values (see text), from bottom to top: $20,30,50,70,120,270 \mathrm{Kg} \mathrm{N}^{-1}$ per year, respectively 

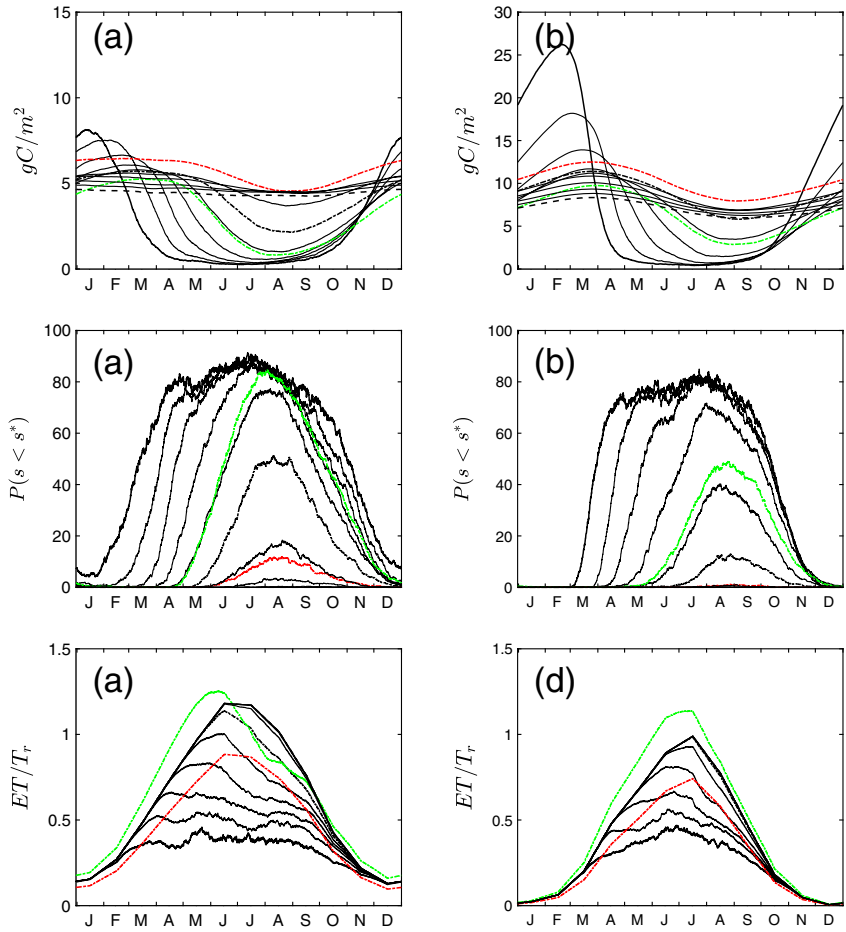

Fig. 9 Soil carbon content, probability of water stress and evapotranspiration flux in rainfed conditions for a Durham, b Minneapolis, c Palermo, d Serra Talhada. Upper row: soil carbon content. Middle row: cumulate probability $P\left(s<s^{*}\right)$ for soil moisture of being under

nitrogen plant uptake rate grows during growing season and remain almost constant during Summer, and decay in Autumn and Winter. Plant uptake is also greatly influenced by the extension and permeability of the paved surfaces. With low extension of impermeable surface, the mean uptake behavior is more constant during the year. On the contrary, with a greater extension of permeable surface, the uptake rates present very pronounced peaks during the growing season. The rainfall effect on $\mathrm{N}$ plant uptake is also evident: in particular Serra Talhada presents a very constant behavior for the $\mathrm{N}$ uptake flux due to the particular
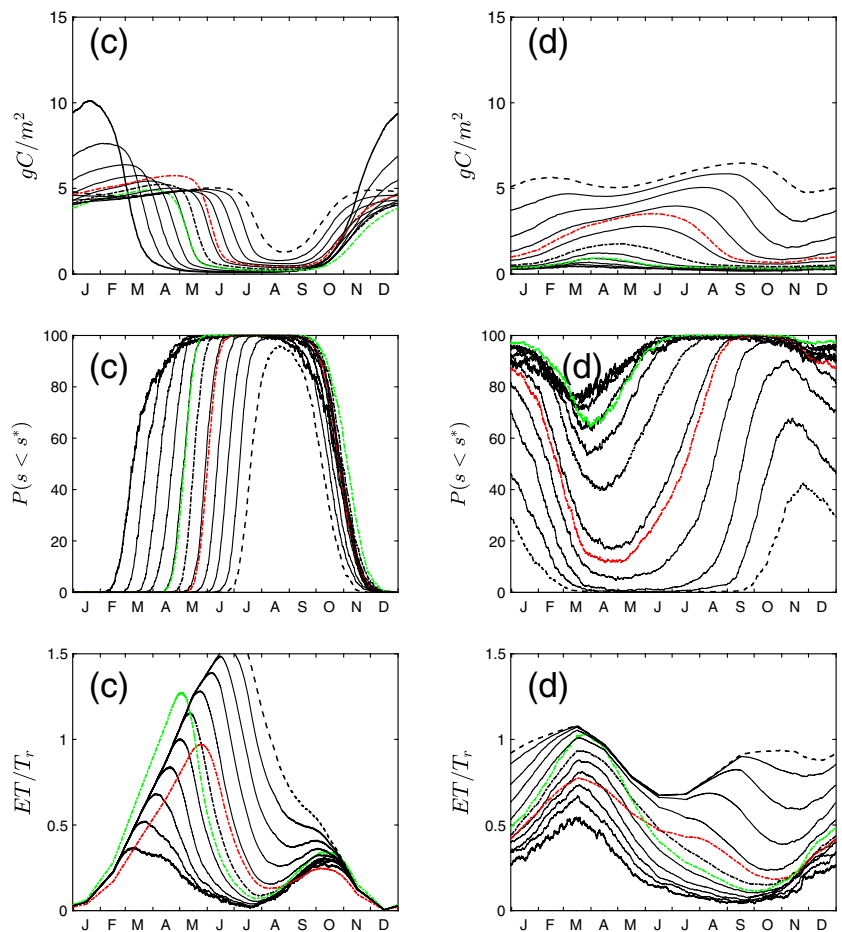

incipient stress soil moisture threshold. Lower row: transpiration normalized with respect reference value $T_{r}$. Figures refer to $\eta_{P}=0.6$. Other values are reported in Table 3 while parameters, line styles and colors are the same as in Fig. 5

climatic conditions. Finally we note that the influence of the reference transpiration rate is reflected in a change of the quantity and the peak position of the plant nitrogen uptake with a difference in time up to 15-30 days.

\section{Soil carbon content, plant water stress and cooling effects}

Figure 9 (upper row) shows the soil carbon for the selected cities and for different amounts of permeable surfaces. The soil carbon content exhibits a great variability along
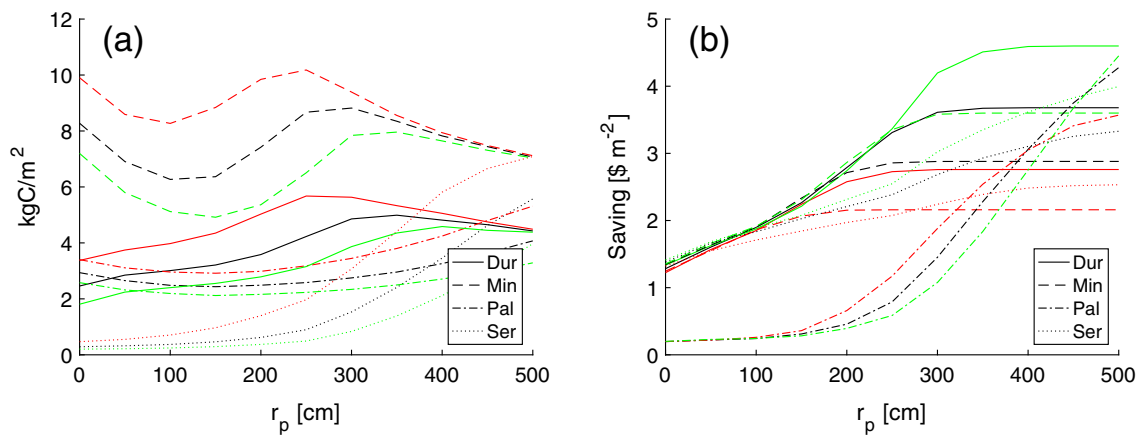

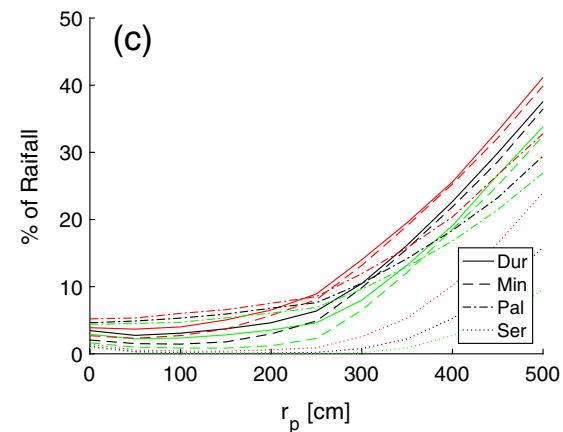

Fig. 10 Quantification of ecosystem services in the four considered cases: a soil carbon content, b saving per each tree related to cooling effect, and $\mathbf{c}$ rainfall percentage losses through runoff and deep percolation. For the sake of comparison, for all cases $\eta_{p}=0.6$, in $\mathbf{a} k=100$ and $(C / N)=70$ and in $\mathbf{b} H=16 \mathrm{~h}$ and $c=0.12 \$ \mathrm{kWh}^{-1}$ (see Wang et al. (2016)). Colors as in Fig. 6. In b the averaged values are calculated from June to August for Durham, Minneapolis and Palermo and from January to March for Serra Talhada 
the year and the influence of seasonality is evident in Minneapolis, Durham and Palermo. Serra Thalada shows a quite constant behavior along the year. The model results seem to support, especially during the warm months, the idea that urban trees can contribute to carbon sequestration but this contribution is not very important. Finally Fig. 10a shows the mean annual soil carbon versus the extension of permeable zone. Some useful indications can be noted: in Durham and Minneapolis it is possible to find an optimal length for the permeable surface that maximize the soil carbon sequestrated, while in Palermo and Serra Thalada, due to the climatic condition, we found that the maximum carbon content is in correspondence of the maximum of permeable surface, i.e., with a situation that is the nearest possible to a natural and indisturbed surface near the tree. The presented results are consistent with the literature findings (see, for example, Nowak and Crane 2002; Raciti et al. 2011). In general the lower the transpiration the higher the soil carbon content. We also note that in the Durham and Minneapolis cases the value are similar with great $r_{P}$ values, while the opposite ocours in Palermo and Serra Thalada cases.

Figure 9 (middle row) shows the probability of being soil moisture under the threshold $s^{*}$, while third row shows corresponding mean evaporation fluxes. The figures clearly shows that a great extension of impermeable surface reduces evapotranspiration flux and the consequent cooling effect. Palermo is, in this sense, emblematic because a low permeable surface (see bold line in Fig. 9-lower row) leads to evaporation losses that can be less in Summer than Autumn and Spring. The evapotraspiration is directly related to energy through the latent vaporization heat, so for each tree and for different periods of year it is possible to estimate the value of energy losses by evapotraspiration that, in turn, can lead to an estimation of the energy saving.

Figure $10 \mathrm{~b}$ shows the saving for the four considered cities versus the amount of permeable surface. The data are consistent with literature findings that show an estimate of 1-5 $\$ \mathrm{~m}^{-2}$ in similar situations (see, for example, the city of Phoenix (AZ-USA) reported by Wang et al. 2016). As aspected, the savings increase when a more permeable surface is available. Durham and Minneapolis show a stepped increase followed by a plateaux, i.e., there is an optimal length of $r_{P}$ after which saving remains practically constant. On the other hand, in Palermo the saving is very low for low amount of permeable surface and then it suddenly increases and can reach a value comparable with Durham and Minneapolis. Serra Talhada shows an intermediate behavior with a more or less linear increase of the saving with respect of the permeable area availability. The example shows as a mean economic quantification of cooling effect for a single tree can be of the order of several hundred dollars and that if a careful design of paved surfaces near urban trees can be costly in design stage, the saving amount during years can be advantageous. We also note the great influence of the tree specie, i.e., with different transpiration rate. In particular, as expected, in Durham, Minneapolis and Serra Thalada the lower the transpiration rate, the lower the energy saving, while the Palermo case shows a difference that depends on the amount of permeable surface.

Finally, Fig. 10c shows the ecosystem service due to runoff reduction. As expected, the higher the value of $r_{P}$ the higher the water loss throught run-off and deep percolation. For each case the values are nearly constant for $r_{P}<2.5 \mathrm{~m}$ then they monotonically increase up to values of $30-40 \%$.

\section{Conclusions and perspective}

Ecosystem services provided by urban green spaces have the potential to help mitigate climate change and make cities more livable and sustainable. A quantification of such services begins by estimating ecohydrological and biogoechemical processes and fluxes and how these may be controlled by different design and management strategies of green urban spaces. Here we have focused on water and nutrient fluxes for different geometric configurations of urban street trees.

In particular, the design of the soil compartment (e.g., the extension of bare, permeable and impermeable areas as well as their permeability) exerts a strong control on the soil water and nutrient fluxes; as a result, urban design can be optimazed for ecosystem service enhancement to minimize plant water stress and irrigation requirements while preserving potential cooling and nitrogen retention effects. While there is limited evidence supporting the carbon sequestration efficiency of urban vegetation (e.g., Velasco et al. 2016), nevertheless the model confirms that carbon sequestration can be non negligible and enhanced with proper design.

Seasonal hydroclimatic variability plays a crucial role in modulating water, energy and nutrient fluxes. Design of green urban spaces should carefully account for projected scenarios in seasonal variability, not only mean climates.

While carbon sequestration, nutrient retention and water savings may simply be additive with the increasing number of street trees, scale effects and nonlinear amplifications may play an important role when evaluating cooling effects in cities with several hundreds of street trees; these effects were not investigated here and should be carefully considered in further investigations.

Funding Information This project has received funding from the European Union's Horizon 2020 research and innovation program 
under the Marie Sklodowska-Curie grant agreement "ECO.G.U.S.ECOsystem services for resilient and sustainable cities: an ecohydrological approach for Green Urban Spaces " (\#701914). The work is also supported by USDA Agricultural Research Service cooperative agreement 58-6408-3-027; National Science Foundation (NSF) grants: EAR-1331846, EAR-1316258, and the DGE-1068871 and FESD EAR-1338694.

List of variables used in the model $A_{B}$, Bare soil area; $A_{C}$, Canopy area; $A_{I}$, Impermeable area; $A_{P}$, Permeable area; $A_{R}$, Root Area; $B$, Biomass; $C / N$, Soil C:N; $E T$, Evapotranspiration; $H$, Daylight hours; $I$, Irrigation; $L_{e}$, Leaching; $N$, Soil nitrogen; $N_{i n}$, Soil nitrogen input; $N_{\text {out }}$, Soil nitrogen output; $N_{S O M}$, Nitrogen content in Soil Organic Matter; $R_{n}$, Effective rainfall; $T_{r}$, Daily reference transpiration per tree; $S$, Mean saving for tree cooling effect; $c$, Energy cost; $k, N_{S O M}$ : $N ; k_{i n}, \mathrm{~N}$ input flux per unit area; $k_{m}, \mathrm{~N}$ net decomposition rate; $n$, Soil porosity; $r_{B}$, Bare soil radius; $r_{C}$, Canopy area radius; $r_{I}$, Impermeable soil radius; $r_{P}$, Permeable soil radius; $r_{R}$, Root area radius; $\tilde{s}$, Intervention point; $\hat{s}$, Target point; $s_{f c}$, Field capacity; $s_{1}$, Soil moisture when deep percolation and runoff occur; $s_{w}$, Soil moisture at wilting point; $s^{*}$, Plant water stress; $z_{R}$, Mean root depth; $\Delta$, Canopy interception depth; $\eta_{B}$, Bare soil permeability; $\eta_{I}$, Impermeable soil contribute; $\eta_{P}$, Permeable soil permeability; $\kappa_{C}$, Reduction coefficient.

Open Access This article is distributed under the terms of the Creative Commons Attribution 4.0 International License (http:// creativecommons.org/licenses/by/4.0/), which permits use, duplication, adaptation, distribution and reproduction in any medium or format, as long as you give appropriate credit to the original author(s) and the source, provide a link to the Creative Commons license and indicate if changes were made.

\section{References}

Amador JA, Hull RJ, Patenaude EL, Bushoven JT, Görres JH (2007) Potential nitrate leaching under common landscaping plants. Water Air Soil Pollut 185(1-4):323-333. https://doi.org/10.1007/ s11270-007-9456-3

Barker PA, Peper PJ (1995) Strategies to prevent damage to sidewalks by tree roots. Arbitr J 19(3):295-309. https://doi.org/10.1080/ 03071375.1995.9747072

BassiriRad H, Gutschick V, Sehtiya HL (2008) Control of plant nitrogen uptake in native ecosystems by rhizospheric processses. Quantifying and understanding plant nitrogen uptake for systems modeling 71

Blunt SM (2008) Trees and pavement-are they compatible? Arbitr J 31(2):73-80. https://doi.org/10.1080/03071375.2008.9747522

Bodnaruk EW, Kroll CN, Yang Y, Hirabayashi S, Nowak DJ, Endreny TA (2017) Where to plant urban trees? A spatially explicit methodology to explore ecosystem service tradeoffs. Landsc Urban Plan 157:457-467. https://doi.org/10.1016/j.landurbplan.2016.08.016

Boerema A, Rebelo AJ, Bodi MB, Esler KJ, Meire P (2017) Are ecosystem services adequately quantified? J Appl Ecol 54(2):358370. https://doi.org/10.1111/1365-2664.12696

Bolund P, Hunhammar S (1999) Ecosystem services in urban areas. Ecol Econ 29(2):293-301. https://doi.org/10.1016/S09218009(99)00013-0

Bowler DE, Buyung-Ali L, Knight TM, Pullin AS (2010) Urban greening to cool towns and cities: a systematic review of the empirical evidence. Landsc Urban Plan 97(3):147-155. https://doi.org/ 10.1016/j.landurbplan.2010.05.006
Bratt AR, Finlay JC, Hobbie SE, Janke BD, Worm AC, Kemmitt KL (2017) Contribution of leaf litter to nutrient export during winter months in an urban residential watershed. Environ Sci Technol 51(6):3138-3147. PMID: 28215078. https://doi.org/10.1021/acs. est.6b06299

Brown RD, Vanos J, Kenny N, Lenzholzer S (2015) Designing urban parks that ameliorate the effects of climate change. Landsc Urban Plan 138:118-131. https://doi.org/10.1016/j.landurbplan. 2015.02.006

Byrne DJ, Jinjun Y (2009) Can urban greenspace combat climate change? Towards a subtropical cities research agenda. Aust Plan 46(4):36-43. https://doi.org/10.1080/07293682.2009.10753420

Byrne JA, Lo AY, Jianjun Y (2015) Residents' understanding of the role of green infrastructure for climate change adaptation in Hangzhou, China. Landsc Urban Plan 138:132-143. https://doi. org/10.1016/j.landurbplan.2015.02.013

Calcerano F, Martinelli L (2016) Numerical optimisation through dynamic simulation of the position of trees around a stand-alone building to reduce cooling energy consumption. Energy Build 112:234-243. https://doi.org/10.1016/j.enbuild.2015.12.023

Čermák J, Hruška J, Martinková M, Prax A (2000) Urban tree root systems and their survival near houses analyzed using ground penetrating radar and sap flow techniques. Plant Soil 219(1):103-116

Cregg BM (1995) Plant moisture stress of green ash trees in contrasting urban sites. J Arboric 21(6):271-276

Derkzen ML, van Teeffelen AJA, Verburg PH (2015) REVIEW: quantifying urban ecosystem services based on high-resolution data of urban green space: an assessment for rotterdam, The Netherlands. J Appl Ecol 52(4):1020-1032. https://doi.org/10.1111/13652664.12469

Dobbs C., Martinez-Harms M. J., Kendal D. (2017). In: Ferrini F, Konijnendijk van den Bosch CC, Fini A (eds) Ecosystem services. Taylor \& Francis, New York. https://doi.org/10.4324/ 9781315627106.ch4

Feng X, Porporato A, Rodriguez-Iturbe I (2014) Stochastic soil water balance under seasonal climates. Proc R Soc Lond A: Math Phys Eng Sci 471(2174)

Gago EJ, Roldan J, Pacheco-Torres R, Ordonez J (2013) The city and urban heat islands: a review of strategies to mitigate adverse effects. Renew Suistain Energy Rev 25:749-758. https://doi.org/10.1016/j.rser.2013.05.057

Gómez-Baggethun E, Barton DN (2013) Classifying and valuing ecosystem services for urban planning. Ecol Econ 86:235-245

Grabosky J, Bassuk N (2016) Seventeen years' growth of street trees in structural soil compared with a tree lawn in New York City. Urban For Urban Green 16:103-109. https://doi.org/10.1016/j. ufug.2016.02.002

Grimm NB, Foster D, Groffman P, Grove JM, Hopkinson CS, Nadelhoffer KJ, Pataki DE, Peters DP (2008) The changing landscape: ecosystem responses to urbanization and pollution across climatic and societal gradients. Front Ecol Environ 6(5):264-272. https://doi.org/10.1890/070147

Gundersen P, Callesen I, De Vries W (1998) Nitrate leaching in forest ecosystems is related to forest floor cn ratios. Environ Pollut 102(1):403-407

Iseman TM, Zak DR, Holmes WE, Merrill AG (1999) Revegetation and nitrate leaching from lake states northern hardwood forests following harvest. Soil Sci Soc Am J 63(5):1424-1429

i-Tree (2017) Tools for Assessing and Managing Forest \& Community Trees. https://www.itreetools.org/

Janhäll S (2015) Review on urban vegetation and particle air pollution-deposition and dispersion. Atmos Environ 105:130 137. https://doi.org/10.1016/j.atmosenv.2015.01.052

Johnson TP, Cameron DA, Moore GM (2011) Trees, stormwater, soil and civil infrastructure: synergies towards sustainable urban 
design for a changing climate. In: ISA international conference and tree climbing championships. Sydney

Kaye JP, Groffman PM, Grimm NB, Baker LA, Pouyat RV (2006) A distinct urban biogeochemistry? Trends Ecol Evol 21(4):192-199. https://doi.org/10.1016/j.tree.2005.12.006

Klemm W, Heusinkveld BG, Lenzholzer S, van Hove B (2015) Street greenery and its physical and psychological impact on thermal comfort. Landsc Urban Plan 138:87-98. https://doi.org/10.1016/j. landurbplan.2015.02.009

Kong F, Sun C, Liu F, Yin H, Jiang F, Pu Y, Cavan G, Skelhorn C, Middel A, Dronova I (2016) Energy saving potential of fragmented green spaces due to their temperature regulating ecosystem services in the summer. Appl Energy 183:1428-1440. https://doi.org/10.1016/j.apenergy.2016.09.070

Kramer E, Hsia S, Uhlig R, Scharenbroch B, Fite K (2015) Below and beyond: long-term performance of urban planting systems. Landsc Architect Front 3(6):46-61

Kuo FE, Sullivan WC (2001) Environment and crime in the inner city does vegetation reduce crime? Environ Behav 33(3):343-367. cited By 394. https://doi.org/10.1177/00139160121973025

Lucke T, Beecham S (2011) Field investigation of clogging in a permeable pavement system. Build Res Inf 39(6):603-615. https://doi.org/10.1080/09613218.2011.602182

Ma L, Ahuja LR, Bruulsema T (2008) Quantifying and understanding plant nitrogen uptake for systems modeling. CRC Press, Boca Raton. ISBN 9781420052978

Maas J, Spreeuwenberg P, Van Winsum-Westra M, Verheij RA, de Vries S, Groenewegen PP (2009) Is green space in the living environment associated with people's feelings of social safety? Environ Plan A 41(7):1763-1777. https://doi.org/10.1068/a4196

Mace G, Masundire H, Baillie J, Ricketts T, Brooks T (2005) Biodiversity. In: Hassan R, Scholes R, Ash N (eds) Ecosystems and human well-being: current state and trends: findings of the condition and trends working group. Island Press, Washington, DC, pp 77-122

Matthews T, Lo AY, Byrne JA (2015) Reconceptualizing green infrastructure for climate change adaptation: barriers to adoption and drivers for uptake by spatial planners. Landsc Urban Plan 138:155-163. https://doi.org/10.1016/j.landurbplan.2015.02.010

McPherson EG, Simpson JR, Xiao Q, Wu C (2011) Million trees Los Angeles canopy cover and benefit assessment. Landsc Urban Plan 99(1):40-50. https://doi.org/10.1016/j.landurbplan.2010.08.011

McPherson EG, Xiao Q, Aguaron E (2013) A new approach to quantify and map carbon stored, sequestered and emissions avoided by urban forests. Landsc Urban Plan 120:70-84. https://doi.org/ 10.1016/j.landurbplan.2013.08.005

Meerow S, Newell JP, Stults M (2016) Defining urban resilience: a review. Landsc Urban Plan 147:38-49. https://doi.org/10.1016/j. landurbplan.2015.11.011

Morgenroth J (2008) A review of root barrier research. Arboricult Urban For 34(2):84-88

Morgenroth J, Buchan GD (2009) Soil moisture and aeration beneath pervious and impervious pavements. Arboricult Urban For 35(3): 135-141

Morgenroth J, Buchan G, Scharenbroch BC (2013) Belowground effects of porous pavements-soil moisture and chemical properties. Ecol Eng 51:221-228. https://doi.org/10.1016/j.ecoleng. 2012.12.041

Mullaney J, Lucke T (2014) Practical review of pervious pavement designs. Clean: Soil Air Water 42(2):111-124. https://doi.org/ 10.1002/clen.201300118

Mullaney J, Lucke T, Trueman SJ (2015a) The effect of permeable pavements with an underlying base layer on the growth and nutrient status of urban trees. Urban For Urban Green 14(1):1929. https://doi.org/10.1016/j.ufug.2014.11.007
Mullaney J, Lucke T, Trueman SJ (2015b) A review of benefits and challenges in growing street trees in paved urban environments. Landsc Urban Plan 134:157-166. https://doi.org/10.1016/j.land urbplan.2014.10.013

Mullaney J, Trueman SJ, Lucke T, Bai SH (2015c) The effect of permeable pavements with an underlying base layer on the ecophysiological status of urban trees. Urban For Urban Green 14(3):686-693. https://doi.org/10.1016/j.ufug.2015.06.008

Nidzgorski DA, Hobbie SE (2016) Urban trees reduce nutrient leaching to groundwater. Ecol Appl 26(5):1566-1580. https://doi.org/ 10.1002/15-0976

Nouri H, Beecham S, Kazemi F, Hassanli AM (2013) A review of ET measurement techniques for estimating the water requirements of urban landscape vegetation. Urban Water J 10(4):247-259. https://doi.org/10.1080/1573062X.2012.726360

Nowak DJ, Crane DE (2002) Carbon storage and sequestration by urban trees in the USA. Environ Pollut 116(3):381-389

Parolari AJ, Porporato A (2016) Forest soil carbon and nitrogen cycles under biomass harvest: stability, transient response, and feedback. Ecol Model 329:64-76

Pataki DE, Carreiro MM, Cherrier J, Grulke NE, Jennings V, Pincetl S, Pouyat RV, Whitlow TH, Zipperer WC (2011a) Coupling biogeochemical cycles in urban environments: ecosystem services, green solutions, and misconceptions. Front Ecol Environ 9(1):2736. https://doi.org/10.1890/090220

Pataki DE, Boone C, Hogue T, Jenerette G, McFadden J, Pincetl S (2011b) Socio-ecohydrology and the urban water challenge. Ecohydrology 4(2):341-347

Peters EB, McFadden JP, Montgomery RA (2010) Biological and environmental controls on tree transpiration in a suburban landscape. J Geophys Res Biogeosci 115(G4):G04006. https://doi.org/10.1029/2009JG001266

Peters EB, Hiller RV, McFadden JP (2011) easonal contributions of vegetation types to suburban evapotranspiration. J Geophys Res Biogeosci 116(G1). G01003. https://doi.org/10.1029 /2010JG001463

Pitman SD, Daniels CB, Ely ME (2015) Green infrastructure as life support: urban nature and climate change. Trans R Soc Soc Aust 139(1):97-112. htpps://doi.org/10.1080/03721426.2015. 1035219

Porporato A, D’Odorico P, Laio F, Rodriguez-Iturbe I (2003) Hydrologic controls on soil carbon and nitrogen cycles. I. Modeling scheme. Adv Water Resour 26(1):45-58. https://doi.org/10.1016/ S0309-1708(02)00094-5

Qin Z, Shober AL, Beeson RC, Wiese C (2013) Nutrient leaching from mixed-species florida residential landscapes. J Environ Qual 42(5):1534-1544

Raciti SM, Groffman PM, Fahey TJ (2008) Nitrogen retention in urban lawns and forests. Ecol Appl 18(7):1615-1626. https://doi.org/ 10.1890/07-1062.1

Raciti SM, Groffman PM, Jenkins JC, Pouyat RV, Fahey TJ, Pickett STA, Cadenasso ML (2011) Accumulation of carbon and nitrogen in residential soils with different land-use histories. Ecosystems 14(2):287-297. https://doi.org/10.1007/s10021-010-9409-3

Rodríguez-Iturbe I, Porporato A (2007) Ecohydrology of watercontrolled ecosystems: soil moisture and plant dynamics. Cambridge University Press, Cambridge

Rohr T, Manzoni S, Feng X, Menezes RS, Porporato A (2013) Effect of rainfall seasonality on carbon storage in tropical dry ecosystems. J Geophys Res Biogeosci 118(3):1156-1167

Rosenberg DE, Kopp K, Kratsch HA, Rupp L, Johnson P, Kjelgren R (2011) Value landscape engineering: dentifying costs, water use, labor, and impacts to support landscape choice1. JAWRA J Am Water Resour Assoc 47(3):635-649. https://doi.org/10.1111/j. 1752-1688.2011.00530.x 
Russo A, Escobedo FJ, Zerbe S (2016) Quantifying the localscale ecosystem services provided by urban treed streetscapes in Bolzano, Italy. AIMS Environ Sci 3(environsci-03-00058), 58. https://doi.org/10.3934/environsci.2016.1.58

Salmond JA, Tadaki M, Vardoulakis S, Arbuthnott K, Coutts A, Demuzere M, Dirks KN, Heaviside C, Lim S, MacIntyre H, McInnes RN, Wheeler BW (2016) Health and climate related ecosystem services provided by street trees in the urban environment. Environ Health: A Global Access Science Source 15. https://doi.org/10.1186/s12940-016-0103-6

Scholz M, Grabowlecki P (2007) Review of permeable pavement systems. Build Environ 42(11):3830-3836. https://doi.org/10.1016 /j.buildenv.2006.11.016

Shackleton C (2016) Do indigenous street trees promote more biodiversity than alien ones? Evidence using mistletoes and birds in South Africa. Forests 7(7). https://doi.org/10.3390/f7070134

Sivapalan M, Savenije HH, Blöschl G (2012) Socio-hydrology: a new science of people and water. Hydrol Process 26(8):12701276

Song Y, Li F, Wang X, Xu C, Zhang J, Liu X, Zhang H (2015) The effects of urban impervious surfaces on eco-physiological characteristics of ginkgo biloba: a case study from Beijing, China. Urban For Urban Green 14(4):1102-1109. https://doi.org/10.1016 /j.ufug.2015.10.008

Strahm BD, Harrison RB, Terry TA, Flaming BL, Licata CW, Petersen KS (2005) Soil solution nitrogen concentrations and leaching rates as influenced by organic matter retention on a highly productive douglas-fir site. For Ecol Manag 218(1):74-88

Thompson CW, Roe J, Aspinall P, Mitchell R, Clow A, Miller D (2012) More green space is linked to less stress in deprived communities: evidence from salivary cortisol patterns. Landsc Urban Plan 105(3):221-229. https://doi.org/10.1016/j.landurbplan.2011. 12.015

Tyrväinen L, Pauleit S, Seeland K (2005) In: Konijnendijk C, Nilsson K, Randrup T, Schipperijn J (eds) Benefits and uses of urban forests and trees. Springer, Berlin, pp 81-114. 978-3-54027684-5

Velasco E, Roth M, Norford L, Molina LT (2016) Does urban vegetation enhance carbon sequestration? Landsc Urban Plan 148:99-107. https://doi.org/10.1016/j.landurbplan.2015.12.003

Venkatraman K, Ashwath N (2016) Transpiration in 15 tree species grown on a phytocapped landfill site. Hydrol Curr Res 7(236). https://doi.org/10.4172/2157-7587.1000236

Vico G, Porporato A (2011) From rainfed agriculture to stressavoidance irrigation: I. A generalized irrigation scheme with stochastic soil moisture. Adv Water Resour 34(2):263-271. https: //doi.org/10.1016/j.advwatres.2010.11.010

Vico G, Revelli R, Porporato A (2014) Ecohydrology of street trees: design and irrigation requirements for sustainable water use. Ecohydrology 7(2):508-523. https://doi.org/10.1002/eco.1369

Villa F, Bagstad KJ, Voigt B, Johnson GW, Portela R, Honzák M, Batker D (2014) A methodology for adaptable and robust ecosystem services assessment. PLOS ONE 9(3):1-18. https://doi.org/ 10.1371/journal.pone.0091001

Volder A, Watson T, Viswanathan B (2009) Potential use of pervious concrete for maintaining existing mature trees during and after urban development. Urban For Urban Green 8(4):249-256. https://doi.org/10.1016/j.ufug.2009.08.006

Volder A, Viswanathan B, Watson WT (2014) Pervious and impervious pavement reduce production and decrease lifespan of fine roots of mature sweetgum trees. Urban Ecosyst 17(2):445453. ISBN 10838155

Vos PEJ, Maiheu B, Vankerkom J, Janssen S (2013) Improving local air quality in cities: To tree or not to tree Environ Pollut 183:113122. https://doi.org/10.1016/j.envpol.2012.10.021

Wang P, Sadeghi A, Linker L, Arnold J, Shenk G, Wu J (2008) Simulated soil water content effect on plant nitrogen uptake and export for watershed management. Quantifying and understanding plant nitrogen uptake for systems modeling 277

Yang Y, Endreny TA, Nowak DJ (2011) iTree-Hydro: snow hydrology update for the urban forest hydrology model. J Am Water Res Assoc 47(6):1211-1218. https://doi.org/10.1111/j. 1752-1688.2011.00564.x

Yang Y, Endreny TA, Nowak DJ (2013) A physically based analytical spatial air temperature and humidity model. J Geophys Res Atmos 118(18):10449-10463. https://doi.org/10.1002/jgrd.50803

Young RF (2013) Mainstreaming urban ecosystem services: A national survey of municipal foresters. Urban Ecosyst 16(4):703-722. ISBN 10838155

Wang Z-H, Zhao X, Yang J, Song J (2016) Cooling and energy saving potentials of shade trees and urban lawns in a desert city. Appl Energy 161:437-444

Winn JP, Bellamy CC, Fisher T (2016) EcoServ-GIS: a toolkit for mapping ecosystem services., Version 3.3 edn. Great Britain, The Wildlife Trusts

Zoelch T, Maderspacher J, Wamsler C, Pauleit S (2016) Using green infrastructure for urban climate-proofing: an evaluation of heat mitigation measures at the micro-scale. Urban For Urban Green 20:305-316. https://doi.org/10.1016/j.ufug.2016.09.011 